\title{
Length-Weight Relationships of Some Economic Fishes of Ibeshe Waterside, Lagos Lagoon, Nigeria
}

Josef Bamidele Bolarinwa* and Popoola $\mathbf{Q}$

Department of Fisheries Technology, Lagos State Polytechnic, P.M.B 21606, Ikeja, Lagos, Nigeria

Department of Animal Production Technology, Lagos State Polytechnic, P.M.B 21606, Ikeja, Lagos, Nigeria

\begin{abstract}
This study describes the length-weight relationships (LWR) and condition factor (K) of six (6) fish species of ecological and economic importance found in Ibeshe waterside area of Lagos lagoon, Nigeria. A total of 154 specimens of Chrysichthys nigrodigitatus, Pomadasy jubelini, Elops lacerta, Cynoglossus senegalensis, Polydactylus quadrifilis and Sphraena piscatorium were collected from the local fishermen during the late rainy period for three months (August 2012 to October 2012) and their total lengths (TL) and weights(W) recorded. A high positive correlation significant at 0.01 levels (2-tailed) exists between the weight and total length of each fish using Pearson's correlation coefficient $(+0.90$ to +0.98$)$. The values of constants' $a$ ' and' $b$ ' were determined from the length and weight data when transformed into the growth equation: $\log W=\log a+b \log T L$. The values of $b$ for the fishes varied from -0.15 to 3.38. The growth pattern of Chrysichthys nigrodigitatus was represented by the equation Log W= $2.24-0.15$ Log $\mathrm{TL}$, Pomadasy jubelini by Log W $=-2.32+3.38 \mathrm{Log} \mathrm{TL}$, Elops lacerta by Log W $=0.41+1.04$ Log TL, Cynoglossus senegalensis by $\log \mathrm{W}=-1.37+2.37 \mathrm{Log} \mathrm{TL}$ ), Polydactylus quadrifilis by Log $\mathrm{W}=-1.25+2.33 \mathrm{Log} \mathrm{TL}$ and Sphraena piscatorium by $\log W=-1.11+2.23 \mathrm{Log} T \mathrm{TL}$. These values of "b" shows that most of the fishes collected from the Ibeshe waterside of Lagos lagoon displayed negative allometric growth pattern apart from Pomadasy jubelini. The condition factor $(\mathrm{K})$, a reflection of the well-being and degree of fatness ranged from 0.56 in Sphraena piscatorium to 1.62 in Pomadasy jubelini and all these condition factors fall outside the range recommended as suitable for matured fresh water species in the tropics. This might indicate that Ibeshe waterside may be environmentally unfavourable to fishes in the aquatic ecosystem.
\end{abstract}

Keywords: Length-weight relationship; Condition factor; Allometry; Lagoon; Correlation.

\section{Introduction}

Fish plays an important role in the development of a nation. Apart from being a cheap source of highly nutritive protein, it also contains other essential nutrients required by the body [1]. Nigeria is blessed with abundant natural aquatic resources in marine, estuarine and freshwater environments. The marine components are within the Nigerian 200 nautical miles Exclusive Economic Zone (EEZ) and the coastal waters. The estuarine resources are found in the extensive mangrove ecosystem estimated to cover an area of about 858,000ha. The freshwater components are within extensive river systems, lakes, flood plains and reservoirs scattered over the entire land surface area of over 4,212,500ha [2] as cited by Obasohan and Oransaye [3]. The current status of the so called productive coastal waters is not really known. Efforts have been made in the past by some investigators $[4,5]$ but there is still not enough basic data that could be used in studying the population dynamics of the water bodies.

Length weight relationships of fish are important in fisheries biology because they allow inter related estimation of average weight of fish of a given length group [6] conversion of length growth equation to weight equivalent (i.e., length at age to weight age) in yield per-recruit and related modes, inter specific and inter population morphometric comparison of fish species and assessing the relative well-being of fish population [7]. Pauly [8] stated that length- weight relationships (LWR) provide valuable information on the habitat where the fish lives. In addition, data on length-weight can also provide important clues on climatic and environmental changes and the change in human subsistence practice. However, the size attained by individual fish may vary because of variation in food supply. Length and weight data are useful as standard result of fish sampling programs. These data are needed to estimate growth rates, length and age structures. Lengthweight relationships allow fisheries scientists to convert growth in- length equations to growth-in-weight in stock assessment models. Such applications are evident in the work of Egbal et al. [9] among others. The purpose of this study is to assess the species composition, lengthweight relationships and condition factors of some important fishes in Ibeshe waterside of Lagos lagoon, Lagos State of Nigeria in view of the fact that there is a dearth of these basic data needed in population studies. They are useful in decision making on utilisation, management and conservation of the resources in coastal waters of Lagos State [10].

\section{Materials and Methods}

\section{The study area}

This study was carried out in Ibeshe estuary in Igbogbo/Bayeku Local Government Area of Ikorodu in Lagos State Nigeria. Ibeshe waterside lies between the latitude of $33^{\prime} 11 \mathrm{~S}$ and a longitude of $28^{`} 27$ $\mathrm{W}$ degree. The location is situated $628 \mathrm{~km}$ south west of the approximate centre of Nigeria and $528 \mathrm{~km}$ south west of the capital of Abuja. It opens into the gulf of Guinea through the Lagos harbour which is the only opening to the sea for the entire western lagoons of Nigeria. The lagoon sediments range between mud, sandy mud, muddy sand, and sand [11]. Occupation of the people is fishing. Some engage in full-

*Corresponding author: Josef Bamidele Bolarinwa, Department of Fisheries Technology, Lagos State Polytechnic, P.M.B 21606, Ikeja, Lagos, Nigeria, E-mail: bolabolero2007@yahoo.com

Received September 09, 2013; Accepted October 28, 2013; Published November 16, 2013

Citation: Bolarinwa JB, Popoola Q (2013) Length-Weight Relationships of Some Economic Fishes of Ibeshe Waterside, Lagos Lagoon, Nigeria. J Aquac Res Development 5: 203 doi:10.4172/2155-9546.1000203

Copyright: (C) 2013 Bolarinwa JB, et al. This is an open-access article distributed under the terms of the Creative Commons Attribution License, which permits unrestricted use, distribution, and reproduction in any medium, provided the original author and source are credited. 
time fishing while some are part-time with farming, sawmilling, oil palm processing, and canoe construction as supplements. Artisanal fishers within the lagoon mainly exploit the fisheries using wooden/ dug-out canoes ranging in size from $3 \mathrm{~m}$ to $8 \mathrm{~m}$ long. The canoes are either paddled or powered by small outboard engines, and manned by an average of two men. From these boats, the fishers operate their cast nets, hook and lines, gillnet, stow nets traps, lift nets, long line, basket traps etc [5]. It is a populated place located in the area Lagos in Nigeria. The lagoon form part of the continuous lagoon that stretches from Lake Nokoue in Benin republic to Lagos (Figure 1). A census of all gears operating at the study area was undertaken on the first week of the study period by visiting landing sites very early in the morning and by asking questions from the fisher folks on the operating, frequency of usage and composition of catches of these gears. Fish specimens were procured from artisanal fishers and middlemen at their landing site for the study. Sampling of landed catches was done for a period of 2 months (September 2012 to October 2012).The fishers used a wide range of fishing gear such as hook and line, long line, cast nets, gill nets and traps. From the catches, fish specimens were randomly chosen and identified using keys and descriptions by Holden and Reed [12]. The length-weight relationship was calculated using the least square regression on $\log$ transformation of the equation. The lengthweight relationship was expressed by the equation: $\log W=\log a+b$ $\log \mathrm{L}$ where $\mathrm{W}=$ Weight, $\mathrm{TL}=$ Total Length, $\mathrm{a}=$ exponent describing of the rate of change of weight with length (intercept), $b=$ weight at unit length. The Condition factor, $\mathrm{k}$ was calculated using this formula; $\mathrm{K}=100 \mathrm{~W} / \mathrm{L}^{3}$ while the Pearson correlation coefficient was used to find the strength of relationship between the weight and length of each fish.

\section{Results and Discussions}

The major fish species found in Ibeshe waterside are Pomadasy jubelini (Ikekere), family' Pomadasydae', Sphraenae barracuda, (kuta) of family 'Sphyraenidae', Chrysichthys nigrodigitatus( Obokun) of family' Claroteidae', Elops lacerta (Igun) of family' Elopidae' Polydactylus quadrifilis, (Ofan) of family' Polynemidae' and Cynoglossus senegalensis, (Abo) of family' Cynoglossidae. The total length of Chrysichthys nigrodigitatus ranged from $12.5 \mathrm{~cm}$ to $40 \mathrm{~cm}$ with mean of $23.66 \mathrm{~cm}$ and weight ranged from $60 \mathrm{~g}$ to $600 \mathrm{~g}$ with mean of 131.76 . The condition factor ' $k$ ' is 1.03 . On log transformation, the overall length-weight was represented by $\log \mathrm{W}=2.24-0.15 \mathrm{Log} T \mathrm{~L}$ showing a negative allometric growth pattern. There was a positive correlation of +0.90 which is significant at 0.01 levels (2-tailed) exists between the total length and weight. The total length of Pomadasy jubelini ranged from $13 \mathrm{~cm}$ to $29 \mathrm{~cm}$ with mean of $19.82 \mathrm{~cm}$ and the weight range from $40 \mathrm{~g}$ to $580 \mathrm{~g}$ ( Mean $=126.38 \mathrm{~g}$ ) and condition factor of 1.62 . On the log transformation, the growth pattern was represented by $\log \mathrm{W}=-2.32+3.38 \mathrm{Log} \mathrm{TL}$ showing a positive allometric growth pattern and a high positive correlation ' $r$ ' between the length and weight $(+0.93)$. The ' $b$ ' value was more than 3 thus showing a positive allometric growth pattern. There was a positive high correlation $r=+0.82$ between the length and weight . The condition factor 1.66 shows there is better condition for Pomadasy jubelini in Ibeshe river but fall below the recommended suitable for matured fresh water species. The total length of Elops lacerta ranged from $18 \mathrm{~cm}$ to $25.5 \mathrm{~cm}$ with mean of $21.45 \mathrm{~cm}$ and weight ranged from $40 \mathrm{~g}$ to $140 \mathrm{~g}$ with mean of $66 \mathrm{~g}$ and condition factor $(\mathrm{K})$ of 0.70 . On log transformation, the growth pattern was described by the equation: $\log \mathrm{W}=0.41+1.04$ Log TL showing a negative allometric growth pattern. A high positive correlation which is significant at the 0.01 level (2-tailed) exists between the length and weight of the fish. Bolarinwa [13] reported a similar result with a condition factor $\mathrm{K}$ value of 0.66 , a high positive correlation of $\mathrm{r}=+0.98$ significant at 0.01 level (2-tailed) and $\mathrm{b}$ value of 2.46 were observed for Elops lacerta in the brackish water ponds of Buguma,

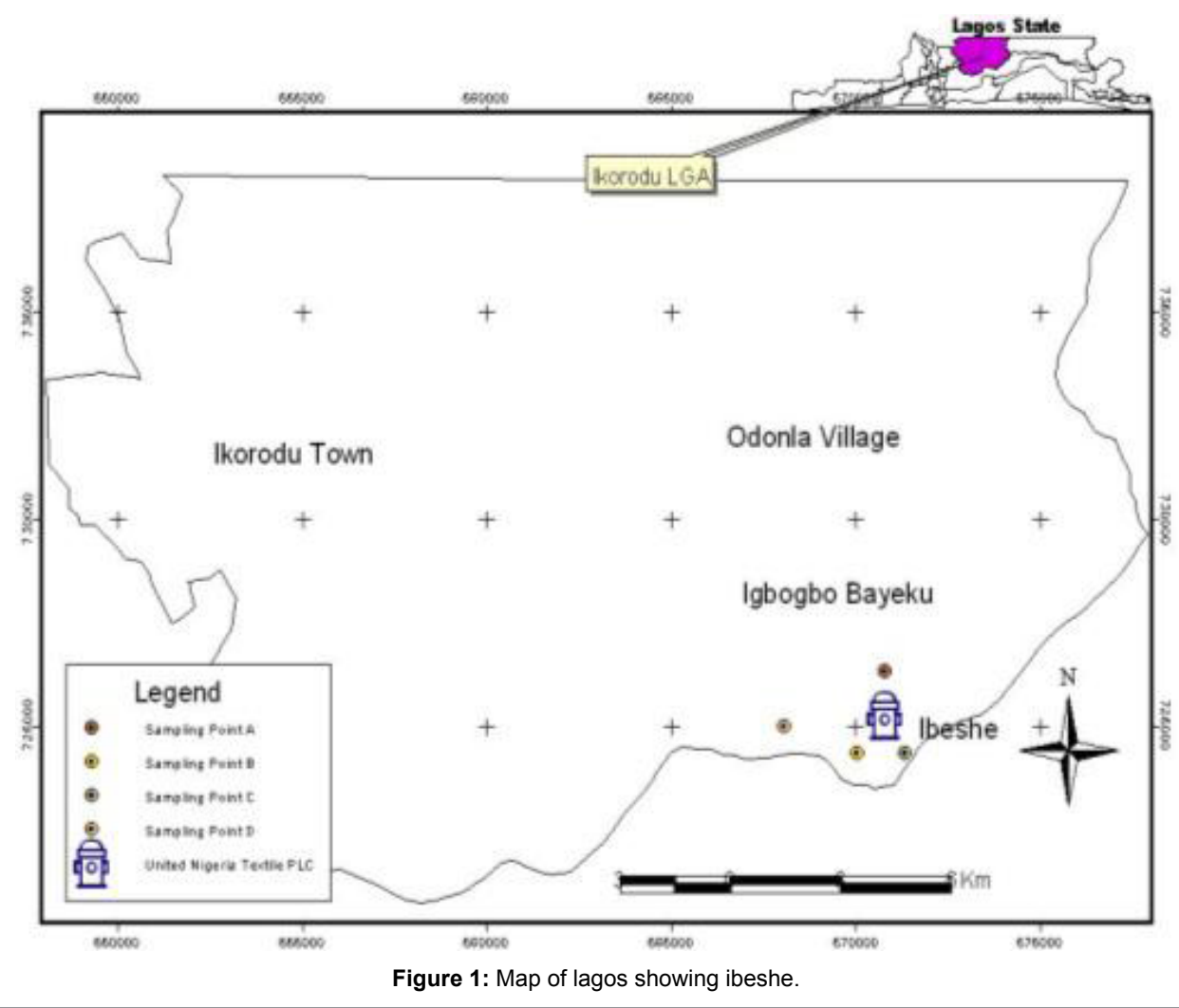




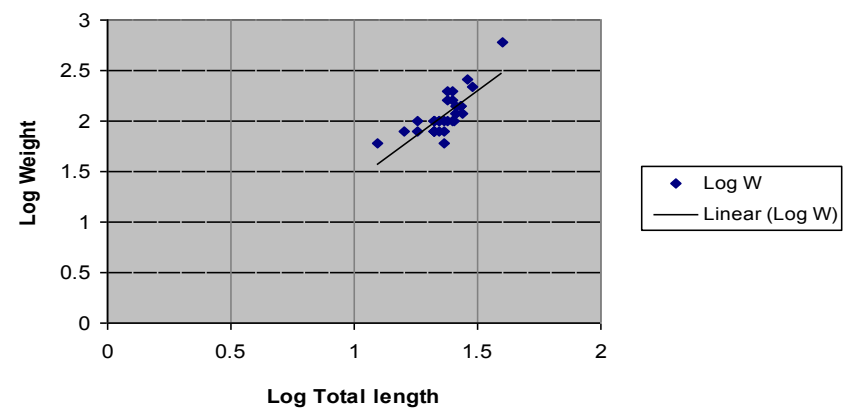

Figure 2: Relationship between weight and total length of Chrysichthys nigrodigitatus.

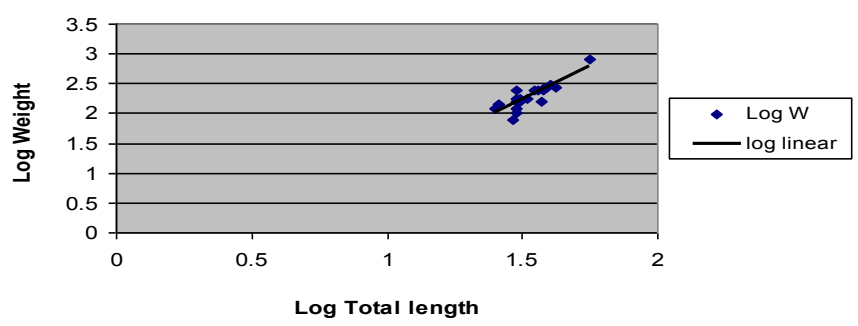

Figure 3: Relationship between weight and total length of Sphyraena piscatorium

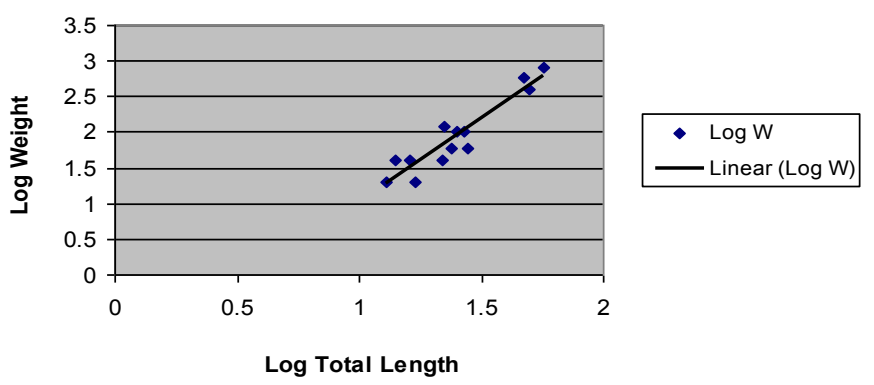

Figure 4: Relationship between weight and total length of Cynoglossus senegalensis.

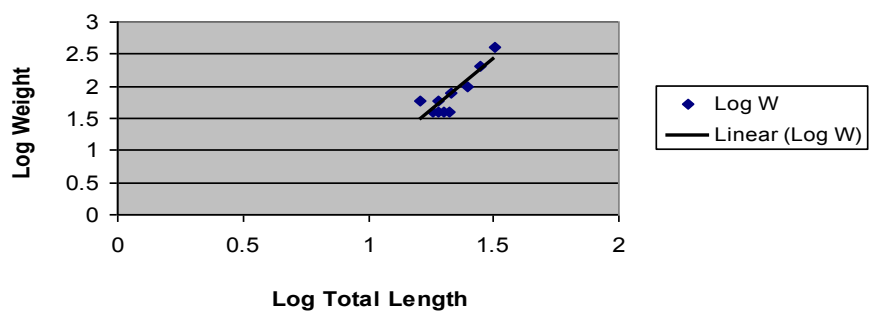

Figure 5: Relationship between weight and total length of Polydactylus quadrifilis.

Rivers State [14]. The total length of Cynoglossus senegalensis ranged from $13 \mathrm{~cm}$ to $57 \mathrm{~cm}$ with mean of $27.63 \mathrm{~cm}$ and weight ranged from $20 \mathrm{~g}$ to $800 \mathrm{~g}$ with mean of $178.89 \mathrm{~g}$ and the condition factor is 0.85 . On log transformation, the overall length-weight was represented by Log W $=-1.37+2.37 \log$ TL showing a negative allometric growth pattern. A high positive correlation of +0.92 significant at 0.01 level (2-tailed) exists between the total length and weight. Abowei et.al [15] reported a negative allometric value for Cynoglossus senegalensis with a b value of 3.5 and a condition factor $(\mathrm{K})$ value of 0.9 in the study of five fish Species from Nkoro River, Niger Delta, Nigeria. The condition factor $(\mathrm{K})$ is similar to what was obtained in Ibeshe but with a difference in the $b$ value. It is likely that this discrepancy is due to seasonal variability of the environment, food availability [16] sampling size and the length interval within different areas or habitat suitability [9] (Figures 2-7). The total length of Polydactylus quadrifilis ranged from $16 \mathrm{~cm}$ to $32 \mathrm{~cm}$ with mean of $21.93 \mathrm{~cm}$ and weight ranged from $40 \mathrm{~g}$ to $400 \mathrm{~g}$ with mean of $106 \mathrm{~g}$ and the condition factor is 1.0 . On log transformation, the growth pattern was described by the equation: $\log \mathrm{W}=-1.25+2.33$ Log TL shows a negative allometric growth pattern. A high positive correlation of +0.98 which is significant at 0.01 level (2-tailed) exists between the length and weight. The total length of Sphraena piscatorium range from $26 \mathrm{~cm}$ to $56 \mathrm{~cm}$ with mean of $34.11 \mathrm{~cm}$ and weight range from $80 \mathrm{~g}$ to $800 \mathrm{~g}$ with mean of $220.90 \mathrm{~g}$. The condition factor was 0.6 . On $\log$ transformation, the overall length-weight was represented by the equation: $\log \mathrm{W}=-1.11+2.23 \mathrm{Log} \mathrm{TL}$ showing a negative allometric growth pattern. A high positive correlation of +0.96 significant at 0.01 level (2-tailed) exists between weight and total length of the fish while its condition factor was 1.22 . The condition factor $(\mathrm{K})$ reflects through its variations information on the physiological state of the fish in relation to its welfare. From a nutritional point of view, there is the accumulation of fat and gonad development [17]. From a reproductive point of view, the highest $\mathrm{K}$ values are reached in some species [18]. $\mathrm{K}$ also gives information when comparing two populations living in certain feeding, density, climate, and other conditions; when determining the period of gonad maturation; and when following up the degree of feeding activity of a species to verify whether it is making good use of its feeding source $[19,20]$. Growth of fish is usually indicated through increase in length and weight is the most appropriate characteristic to determine the population analysis at a particular time. Length weight relationships are of great importance in fisheries management for comparative studies [21].

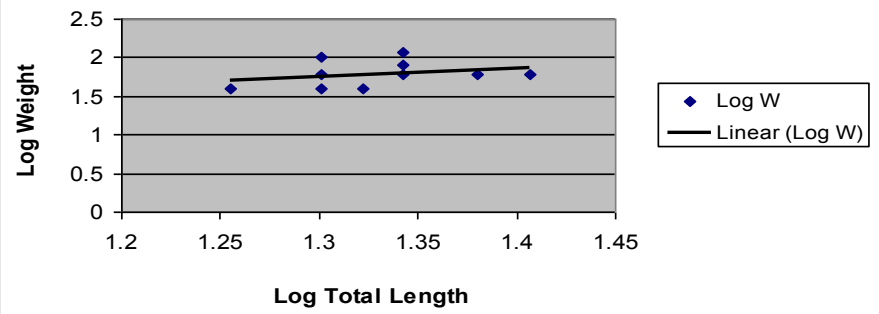

Figure 6: Relationship between weight and total length of Elops lacerta.

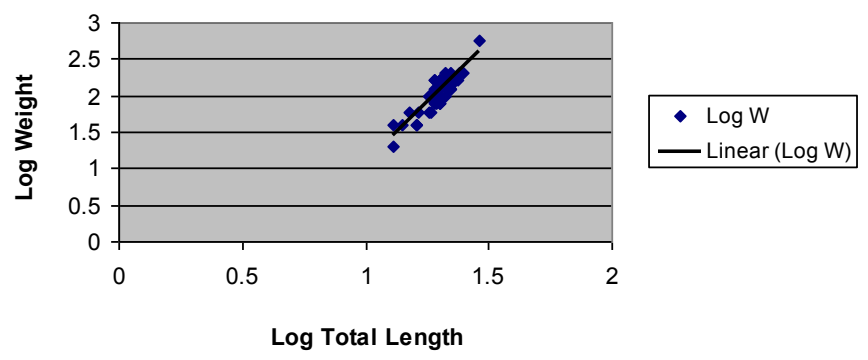

Figure 7: Relationship between weight and total length of Pomadasy jubelini. 
Citation: Bolarinwa JB, Popoola Q (2013) Length-Weight Relationships of Some Economic Fishes of Ibeshe Waterside, Lagos Lagoon, Nigeria. J Aquac Res Development 5: 203 doi:10.4172/2155-9546.1000203

\section{Conclusion and Recommendations}

In this study, almost all the six economic fishes found in Ibeshe waterside except Pomadasy jubelini showed negative allometric growth pattern. This corroborates with the findings of Kumolu-Johnson and Ndimele [22] who reported majorly negative allometric growth patterns in the study of the Length-weight relationships of nine fish species from Ologe Lagoon, Lagos. However, there is a need for more in depth investigations that would contain a larger volume of data of length and weight of fishes in Ibeshe over a longer period of time. Based on the result of the study, the condition factor of the fish ranged from 0.56 and 1.62 which falls outside the range $(2.4-4.8)$ recommended as suitable for matured fresh fish by Bagenal and Tesch [23]. This could have been caused by adverse environmental factors like pollution as a result of anthropogenic activities like sawmilling, sewage disposal and presence of industrial effluents [24-26]. This suggests the condition of Ibeshe river in comparison to fresh water bodies may be unfavourable to fishes in the River. Therefore, there might be a need for more in depth studies on the physicochemical properties and the condition factors of other fish species in Ibeshe waterside to establish the suitability of the river for fish survival.

\section{References}

1. Sikoki FD, Otobotekere AJT (1999) Fisheries. In: The Land People of Bayelsa State Central Niger Delta EC Alagoa, (Ed.) Port Harcourt 301-319.

2. Ita EO (1993) Inland Fishery Resources of Nigeria. FAO CIFA Occasional Paper No 20: 120.

3. Obasohan EE, Oransaye JAO (2006) Biodiversity and Sustainability of Freshwater Fishes of Nigeria, FISON Proceedings 230-237.

4. Egborge ABM (1992) Problems of Aquatic Resources Conservation. A Case study of Nigerian Fishes. In Proceedings of the National Conference on Aquatic Resources, Calabar 27.

5. King RP (1998) Physiochemical indices of the fisheries potential of a Nigerian rain forest pond. Journal of Aquatic Science 13: 49-54.

6. Beyer JE (1987) On length-weight Relationships. Part I: Computing the mean weight of the Fish of a given length class. Fishbyte 5: 11-13

7. Bolger T, Connoly PL (1989) The Selection indices for the Measurement and Analysis of Fish condition. J Fish Biol 17: 1-182.

8. Pauly D (1993) FishByte Editorial. Naga, ICLARM Q 16: 26.

9. Egbal OA Mohammed EA, Afra AA (2011) Length-weight relationships and condition factors of six species in Atbara River and khashin El-girba reservoir , Sudan. International Journal of Agricultural Sciences 3: 66-70.
10. Agboola JI, Anetekhai MA (2008) Length-weight Relationships of Some Fresh and Brackish Water Fishes in Badagry Creek, Nigeria. J Appl Ichthyol 24: 623625.

11. Soyinka OO, Kusemiju K (2007) The growth pattern, food and feeding habits of young bonga (Ethmalosa fimbriata (BOWDICH) from Lagos and Lekki lagoons, Nigeria, Nigerian Journal of Fisheries 4: 1-4

12. Reed W, Burschard J, Hopson AJ, Jenness J, Yaro I (1967) Fish and Fisheries of Northern Nigeria. Min of Agriculture, Northern Nigeria 226.

13. Bolarinwa JB (2012) Growth Pattern, Feeding Habit and condition factor of Elops lacerta in its brackish water pond of Buguma, Niger State. International Journal on Agriculture 2: 23-26.

14. Bolarinwa JB (1984) Study of Elops lacerta and other extraneous fishes in the brackish water ponds of Buguma, Rivers State. M Tech Thesis submitted to Rivers State University of Science \& Technology, Port Harcourt, Nigeria.

15. Abowei JFN, Davies OA (2009) Some Population Parameters of Clarotes laticeps (Rupell, 1829) from the fresh water reaches of the lower river, Niger Delta, Nigeria. Am J Sci Res 15-19.

16. Mommsen TP (1998) Growth and Metabolism. In: Evans, DH (Ed.) The Physiology of Fishes. CRC Press, New York 65-98.

17. Le Cren CP (1951) Length-weight relationship and seasonal cycle in gonad weight and condition in perch. (Perva fluviatilis) Journal of Animal Ecology 20: 201-219.

18. Hart Al, Abowei JFN (2007) A Study of the length-weight Relationship, condition factor and age of ten fish species from the lower Nun river. Niger Delta Afri J of Applied Zool Environ Biol 9: 13-19.

19. Kulbicki M, Guillemot N, Amand M (2005) A general approach to length-weight relationships for New Caledonian lagoon fishes. Cybium 29: 235-252.

20. Weatherley AH, Gill HS (1987) The Body of Fish Growth. London: Academic Press 443.

21. Moutopoulos DK and Stergiou KI (2002) Length weight and length-length relationship of fish species of fish species from Aegean Sea (Greece). J Appl L chthyol 18: 200-203

22. Kumolu-Johnson CA, Ndimele PE (2010) Length-Weight relationships and condition factors of twenty-one fish species in Ologe lagoon, Lagos, Nigeria. Asian Journal of Agricultural Sciences 2: 174-179.

23. Bagenal TB, Tesch AT (1978) Conditions and Growth Patterns in Fresh Water Habitats. Oxford, Blackwell Scientific Publications 75-89.

24. Anene A (2005) Condition Factors of cichid species of man-made lake in Imo State, Southeast, Nigeria. Turk J Fish Aquat Sci 5: 43-47.

25. Alfred-Ockiya JF (2000) The length-weight Relationship of Snake Head (Chana chana) from the Fresh Water Swamps of Niger Delta. J Aquatic Sci 15: 12-14.

26. Olawusi-Peters $\mathrm{OO}$ (2008) Ecological evaluation of the effects of anthropogenic activities on sustainable fish production in Agboyi Creek, Lagos State, PhD thesis, University of Ibadan. 